\title{
Translation Quality and Awareness of Cultural Translation Theories
}

\author{
Farzaneh Farahzad \\ Allameh Tabatabai University, Tehran, Iran \\ Parviz Azhideh \\ Tabriz University, Tabriz, Iran \\ Leila Razmjou \\ Tabriz University, Tabriz, Iran \\ Email: leilarazmjou@gmail.com
}

\begin{abstract}
The present paper reports a study carried out to examine the possible outcomes of incorporating cultural translation theories and its subcomponents to translation syllabi and highlight their possible positive effects on translation quality of EFL learners and translation trainees in Iranian universities.150 Iranian undergraduate students took part in this study. They were divided into three groups -one experimental and two control groups. After homogenizing the participants through a TOEFL test, a translation pre-test was given to them and then cultural theories of translation like Venuti's model were taught to the experimental group who were later required to use the taught material in their classroom translation practice during one academic semester. The control groups were run traditionally as widely practiced in Iranian undergraduate translation classes. A translation post-test was given to all the groups at the end of the semester. The statistical results demonstrate a significant difference between the pre- and post- tests in the experimental group as compared with the control groups.
\end{abstract}

Index Terms - translation theories, cultural theories, translation pedagogy, translation quality, translator training

\section{INTRODUCTION}

Languages live and grow just as human beings do. Human beings need interaction and communication and so do languages. This interaction is materialized through translating. The importance of translating is further highlighted when we take the new world of information exchange and globalization into consideration. During the recent decades, "Translation Studies" has found its place as a new and independent discipline which requires its own theories, techniques, principles, and approaches. This fact, however, has not been widely recognized yet, especially in my country (Iran), and this is due to the nature of translating. As Federici (2007) maintains: "translation is certainly a highly skilled activity, a first-class art based on a high level of competence not only in the two languages but in both cultures" (p.152). Thus, the translating process can be said to have a dual nature: scientific and artistic. The artistic nature is widely accepted while its scientific nature has yet to be recognized and investigated. The scientific part of translation requires its own curriculum, methodologies, syllabi, and teacher expertise. That is why Davies (2004) views the translation teacher as playing a double role as both an expert in the field of translation and an expert in teaching (p.2).

The new approaches to teaching translation embrace inclusion of theories of translation, text functions and text type awareness in their curricula and syllabi. Davies (2004) suggests that the "read and translate" directive to teach translation is probably as obsolete and unproductive as the Grammar-Translation Method is to teach a foreign language (p.3). Several authors and researchers in the field have written about the role translation theories, text types and awareness of text functions can have in enhancing translation abilities of translator trainees (Newmark 1988;- Gentile 1991;- Gile 1991;-Munday 2001;- Bassnett 2002;- Chesterman \& Wagner 2002). This study aims to investigate the impacts that awareness of cultural translation theories has on the translation quality of translator trainees.

The undergraduate English major programs in Iranian universities include translation courses as a core component. In most translation classes, the "read and translate" strategy (Davies, 2004) is the most common event which takes place. Most translation courses are taught by instructors whose major is TEFL and whose knowledge of translation theories is very limited. Most instructors are unaware of the recent findings in translation studies because this is not their major, although they are expected to be able to teach translation. The reason behind this is that the depth, and complexities of the nature of translating are not yet recognized, not even in our academia. Moreover, it is widely known that theory and practice are complementary while most translation instructors in our universities are not into the practice of translation themselves.

A. Translation Theory 
Flourishing of translation theories and expansion of new ideas towards the translating process was a turning point in translation studies. Gentile (1991) maintains: "practice which is not informed by a theoretical framework, suffers from the idiosyncrasies of practitioners" (p.344). Gile (1991) also mentions the potential advantages of incorporating theoretical components into translator training programs, thereby: "accelerating and enhancing the scope of students' progress, helping them make appropriate decisions in new situations and maintaining appropriate strategies and tactics" (p.185). However, he has not performed any empirical studies to validate his findings in authentic pedagogical settings.

The purpose of translation theory, according to Bassnett (2002), is to reach an understanding of the processes undertaken in the act of translation. Theory and practice are indissolubly linked, and are not in conflict (p.43-4). However, Chesterman \& Wagner (2002) mention that we can make some guesses based on intuition or experience in this regard, but we need more empirical evidence before we can make good predictions (p.64). Also, Davies (2004) confirms the above point by asserting that translation studies has a multifaceted character and is a complex and still relatively unexplored area of study which lacks a rich pedagogical tradition (p.11).

\section{B. The Study}

The present study was designed to see whether or not awareness of cultural theories of translation improves the quality of students' translations at the undergraduate level.

\section{METHODOLOGY}

About 150 Iranian undergraduate students from two different universities in Tabriz, Iran took part in this study. The students from Tabriz University majored in English literature and the students from Maragheh Azad University majored in ELT. The subjects were informed at the beginning of the semester that they were participating in a study for the purpose of enhancing translation pedagogy. The course devoted to the study was a translation course offered to students who had already passed two basic courses on translation, but no course on theories of translation. All the subjects were Iranian and factors such as age and sex were assumed to be randomly distributed.

Procedure

The students in Tabriz University were assigned as the experimental group and Maragheh Azad University students were assigned as two control groups. Tabriz University students were assigned as the experimental group because they were only one group while Maragheh University students were two groups and the way their classes were run and the kind of practice applied in the class and the methodology should have been equal for both groups. A TOEFL test was administered to all the subjects at the beginning to secure homogeneity in terms of English language competence. Then, a translation test (from English to Persian) was given to all groups at the beginning of the semester as a pre-test. After the pre-test, the treatment started which included teaching cultural theories to the experimental group during the whole semester. The translation practices which took place besides teaching the theories were based on Davies' (2004) description of a student and learning-centered context that focuses on collaborative study and exploration of the translation process with the teacher acting as guide. The students practiced translating in groups and they consulted with one another within the groups while the teacher was available to exchange views among the groups. This was done to maintain the student centered context mentioned above. The texts chosen for translation practice in the classes reflected the points highlighted by the theories. In teaching cultural theories to the undergraduate students in the experimental group, raising cultural awareness of the cultural references in the text, and helping them transfer these references in the target language was done in the class as suggested by Davies (2004) since cultural immersion may take a longer time to be achieved than linguistic competence (p.86). Davies citing Duff (1981) suggests that a course which includes explicit teaching should be designed at two levels: a/ the pedagogical, where the teacher makes sure that a wide range of cultural issues will be dealt with in an organized and graded way, and b/ the professional, where the students are made aware of the issue of subjectivity and of the different strategies they can use to transfer cultural references (p.86).

Other teaching strategies adopted from Davies (2004) in the experimental class included:

- Explicitation: some information is added to the text in TL.

- Exoticism: The SL is kept with no changes in the translation

- Cultural transplantation: the reference has been completely adapted to the target culture or has been substituted by a reference which is more in accordance with the norms of the TC or has been changed for ideological reasons.

- Cultural Borrowing: the SL word or expression is rendered without change in the TL

- Calque: the TL is similar to the SL word or expression

- Transliteration: the cultural referent is changed according to the phonic conventions of the TL (e.g. bumeran (boomerang) in Spanish)

- Communicative: the SL referent has an identifiable correspondence in the TL

- Neutralization: the connotations of a segment is diminished (p.90-92)

Meanwhile, raising students' awareness of the importance of context to understand the associations behind a cultural reference was also emphasized in the class (p.94). Exploring different translations of the same text and studying the historical and political context of each one was practiced (p.98). Exploring degrees of intersection between languages and how cultural bridges may be built and differences highlighted, not eliminated were brought into their attention (p.103). Peer editing was practiced (p.106). Reflecting on the danger of literal translation was also emphasized (p.115). 
Other activities done in the class included:

- showing students examples of mistranslations of food and drink: menus, recipes, and so on, and decide what has gone wrong and why (p.85).

- awareness-raising: the students receive a brief text with cultural references as an assignment to be discussed in session (p.88).

- orientation activities: the students write a draft translation of a chosen extract and underline the problems directly related to cultural references (p.95).

- exposing students to mistranslations found in the mass media, publishes specialized or literary translations, signs, and notices, etc. In pairs or groups, students deverbalize and interpret the meaning of the mistranslation and then backtranslate to reach an agreement as to the probable original message and the reasons for the mistranslation (syntactic, lexical, cultural, etc) and finally rewriting it correctly (p.115). This way, their awareness of interferences can be highlighted and can help them not to fall into the same traps (p.118).

The control groups received no treatment with regard to theories and were in fact a traditional kind of translation class, which is the commonest type of translation class prevalent in Iranian universities. This type of translation class is what Davies (2004) depicts as 'the traditional product-oriented and teacher-centered learning context' (p.14). In such contexts, students have a minor role in deciding about their translation decisions and teachers usually single out model translations.

At the end of the semester, another translation test (from English to Persian) was given to the students as a post-test. Students' translations in the pre- and post-tests were assessed based on the model presented by Farahzad (1992) called objectified scoring. It presupposes a careful examination of the target text. The model takes the sentence as the units of translation and the verb as the marker of a sentence, which is assigned a score. In the model complex sentences are broken down into main and sub-clauses, each receiving a separate score (p.277). The model also accounts for cohesion and style which cannot be checked and scored at the sentence and clause level but leaves the determination of the weight of their scores to the examiner. As such, the target texts were read two times, first for accuracy and appropriateness, then for cohesion and style.

To ensure the inter-rater reliability of the test results, another rater who was also a translation instructor was asked to rate the translations based on the above-mentioned model. The scores given by the two examiners were compared; the scores`yielding no significant difference was to be indicative of precision and reliability in scoring. This was implemented through employing a paired t-test the results of which are shown in table1:

TABLE1

PAIRED SAMPLES STATISTICS

\begin{tabular}{|ll|l|l|l|l|}
\hline & & Mean & $\mathrm{N}$ & Std. Deviation & Std. Error Mean \\
\hline Pair 1 & cul1.1.pr & 11.0861 & 220 & 1.26632 & .08538 \\
& cul1.2pr & 11.0963 & 220 & 1.25550 & .08465 \\
\hline
\end{tabular}

TABLE 2

PAIRED SAMPLES TEST

\begin{tabular}{|c|c|c|c|c|c|c|c|c|}
\hline \\
\hline & \multicolumn{5}{|c|}{ Paired Differences } & \multirow[t]{3}{*}{$\mathrm{t}$} & \multirow[t]{3}{*}{$\mathrm{df}$} & \multirow{3}{*}{$\begin{array}{l}\text { Sig. } \\
\text { (2-tailed) }\end{array}$} \\
\hline & \multirow[t]{2}{*}{ Mean } & \multirow{2}{*}{$\begin{array}{l}\text { Std. } \\
\text { Deviati } \\
\text { on }\end{array}$} & \multirow{2}{*}{$\begin{array}{l}\text { Std. } \\
\text { Error } \\
\text { Mean } \\
\end{array}$} & \multicolumn{2}{|c|}{$\begin{array}{l}95 \% \text { Confidence Interval } \\
\text { of the Difference }\end{array}$} & & & \\
\hline & & & & Lower & Upper & & & \\
\hline Pair 1 cul1.1.pr - cul1.2pr & -.01023 & .13995 & .00944 & -.02882 & .00837 & -1.084 & 219 & .280 \\
\hline
\end{tabular}

The results taken from the data shown in Table 2 reveal that there is no significant difference between the scores checked by the two examiners ( $\mathrm{p}>0.05)$.

Therefore, the hypothesis that there is no significant difference between the scores checked by the two examiners (p>0.05) is not rejected.

\section{RESULTS AND DISCUSSION}

To verify the homogeneity of the TOEFL test scores obtained from the experimental and control groups a one-way ANOVA test was calculated. The results are shown in Tabels 3 and 4. The results of table 3 indicate that there is no significant difference between scores obtained in the TOEFL test in Tabriz and Maragheh groups $(\mathrm{P}>0.05)$. In table 4, the mean of TOEFL scores of these three groups have been calculated. It indicates that there is no significant difference between the scores and all students are at the same level.

TABLE 3

\begin{tabular}{|l|l|l|l|l|c|}
\hline & TABLE 3 \\
\hline Between Groups & Sum of Squares & df & Mean Square & F & Sig. \\
\hline Within Groups & 29005.419 & 2 & 14502.710 & 103.968 & .560 \\
\hline Total & 22597.708 & 162 & 139.492 & & \\
\hline
\end{tabular}




\begin{tabular}{|l|l|l|}
\multicolumn{3}{|c}{ TABLE 4 } \\
\hline \multirow{3}{*}{ nomre.kol } & group & Statistic \\
\cline { 2 - 3 } & maraghe1 Mean & 37.3243 \\
\cline { 2 - 3 } & tabriz Mean & 37.5000 \\
\cline { 2 - 3 } & maraghe2 Mean & 37.2750 \\
\hline
\end{tabular}

The mean of the experimental and control groups are shown below:

TABLE 5:

DESCRIPTIVES (PRE-TEST)

\begin{tabular}{|l|l|l|l|}
\hline Group & \multicolumn{2}{|l|}{} & Statistic \\
\hline cul.pr & Maragheh1 & Mean & 9.86 \\
\cline { 3 - 4 } & & Std. Deviation & 1.47 \\
\cline { 2 - 4 } & tabriz & Mean & 10.7371 \\
\cline { 3 - 4 } & & Std. Deviation & 1.17580 \\
\cline { 2 - 4 } & Maragheh2 & Mean & 9.98 \\
\cline { 3 - 4 } & & Std. Deviation & 0.921 \\
\hline
\end{tabular}

TABLE 6:

DESCRIPTIVES (POST-TEST)

\begin{tabular}{|l|l|l|l|}
\hline Group & \multicolumn{2}{|l|}{} & Statistic \\
\hline cul.po & \multirow{2}{*}{ Maragheh1 } & Mean & 10.75 \\
\cline { 3 - 4 } & & Std. Deviation & 1.23 \\
\cline { 2 - 4 } & \multirow{2}{*}{ Tabriz } & Mean & 11.84 \\
\cline { 3 - 4 } & & Std. Deviation & 1.20 \\
\cline { 2 - 4 } & \multirow{2}{*}{ Maragheh2 } & Mean & 11.23 \\
\cline { 3 - 4 } & & Std. Deviation & 1.129 \\
\hline
\end{tabular}

Hypothesis 1. The new cultural method has no impact on the learning achievement of the students in the first control group (Maragheh 1).

The Table (7) maps the results of the paired t-test as a way to analyze the discrepancies between the scores obtained in the pre- and post-cultural method stages.

TABLE 7:

THE STATISTICAL INDEXES FOR ANALYSIS OF PRE- AND POST-CULTURAL METHOD SCORES

\begin{tabular}{|l|l|l|l|l|}
\hline \multicolumn{2}{|c|}{} & Mean & $\mathrm{N}$ & Std. Deviation \\
\hline \multirow{2}{*}{ Pair 1 } & cul.po & 10.7500 & 38 & 1.23299 \\
\cline { 2 - 5 } & cul.pr & 9.8618 & 38 & 1.47810 \\
\hline
\end{tabular}

TABLE 8:

PAIRED SAMPLES TEST

\begin{tabular}{|c|c|l|l|l|l|l|l|l|}
\hline & \multicolumn{3}{|l|}{ Paired Differences } & t & df & $\begin{array}{l}\text { Sig. } \\
(2 \text {-tailed })\end{array}$ \\
\cline { 2 - 6 } & Mean & $\begin{array}{l}\text { Std. } \\
\text { Deviation }\end{array}$ & $\begin{array}{l}\text { Std. } \\
\text { Error } \\
\text { Mean }\end{array}$ & $\begin{array}{l}\text { 95\% Confidence Interval } \\
\text { of the Difference }\end{array}$ & Lower & Upper & \\
\hline Pair 1 cul.po - cul.pr & .88816 & 1.87056 & .30344 & .27332 & 1.50299 & 2.927 & 37 & .06 \\
\hline
\end{tabular}

The results in the Table (8) establish that there is no significant difference between scores obtained in the pre- and post-cultural method stages. $(\mathrm{p}>0.05)$

As a result the research hypothesis that there is no significant difference between scores obtained in the pre- and post-cultural method stages is not rejected. ( $p>0.05)$ Maragheh students are all in control group undergoing no teaching programme; hence, it is natural that their scores underwent no fluctuations from one exam to another.

Hypothesis 2. The new cultural method has no impact on the learning achievement of the students of the second control group (Maragheh 2).

The results of the paired t-test are illustrated in Table (9) as a way to analyze the discrepancies between the scores obtained in pre- and post-cultural stages.

TABLE (9):

THE STATISTICAL INDEXES FOR ANALYSIS OF THE PRE- AND POST-CULTURAL SCORES

\begin{tabular}{|l|l|l|l|l|}
\hline \multicolumn{2}{|c|}{} & Mean & N & Std. Deviation \\
\hline \multirow{2}{*}{ Pair 1 } & cul2.po & 11.2372 & 39 & 1.12967 \\
\cline { 2 - 5 } & cul2.pr & 9.9872 & 39 & .92115 \\
\hline
\end{tabular}

\begin{tabular}{|l|l|l|l|l|l|l|l|l|}
\hline \multirow{2}{*}{} & Paired Differences & $\mathrm{t}$ & df & $\begin{array}{l}\text { Sig. } \\
(2-\text { tailed })\end{array}$ \\
\cline { 2 - 6 } & Mean & $\begin{array}{l}\text { Std. } \\
\text { Deviation }\end{array}$ & $\begin{array}{l}\text { Std. } \\
\text { Error } \\
\text { Mean }\end{array}$ & $\begin{array}{l}\text { 95\% Confidence Interval } \\
\text { of the Difference }\end{array}$ & Lower & Upper & & \\
\hline Pair 1 cul.po - cul.pr & 1.25000 & 1.19208 & .19089 & .86357 & 1.63643 & 6.548 & 38 & .0 .4 \\
\hline
\end{tabular}


The results in Table (10) verify that there is no significant difference between the scores obtained in the pre- and post-cultural method stages. (p>0.05)

Hence the hypothesis that there is no significant difference between the scores obtained in pre- and post-cultural method stages is not rejected. (p>0.05) In the present study, Maragheh students are all in control group undergoing no teaching programme, so it is natural that their scores did not change from one exam to another.

Hypothesis 3. The new cultural method has no impact on the learning achievement of the students of the experimental group (Tabriz).

The results of the paired t-test are illustrated in Table (12) as a way to analyze the discrepancies between the scores obtained in pre- and post-cultural method stages.

TABLE (11):

THE STATISTICAL INDEXES FOR ANALYSIS OF THE PRE- AND POST-CULTURAL SCORES

\begin{tabular}{|l|l|l|l|l|}
\hline & & Mean & $\mathrm{N}$ & Std. Deviation \\
\hline \multirow{2}{*}{ Pair 1 } & cul1.pr & 10.7371 & 58 & 1.17580 \\
\cline { 2 - 5 } & cul1.po & 11.8491 & 58 & 1.20 \\
\hline
\end{tabular}

PAIRED SAMPLES TEST 12

\begin{tabular}{|c|c|c|c|c|c|c|c|c|}
\hline & \multicolumn{5}{|c|}{ Paired Differences } & \multirow[t]{3}{*}{$\mathrm{t}$} & \multirow[t]{3}{*}{ Df } & \multirow{3}{*}{$\begin{array}{l}\text { Sig. } \\
\text { (2-tailed) }\end{array}$} \\
\hline & \multirow[t]{2}{*}{ Mean } & \multirow[t]{2}{*}{$\begin{array}{l}\text { Std. } \\
\text { Deviation }\end{array}$} & \multirow{2}{*}{$\begin{array}{l}\text { Std. } \\
\text { Error } \\
\text { Mean }\end{array}$} & \multicolumn{2}{|c|}{$\begin{array}{l}95 \% \text { Confidence Interval } \\
\text { of the Difference }\end{array}$} & & & \\
\hline & & & & Lower & Upper & & & \\
\hline Pair 1 cul1.pr - cul1.po & -1.11207 & 1 & .80903 & -2.73213 & .50799 & -1.375 & 57 & .017 \\
\hline
\end{tabular}

The results in Table (12) substantiate that there is a significant difference between the scores obtained from the students of Tabriz in pre- and post-cultural method stages. $(\mathrm{p}<0.05)$

Therefore, the hypothesis that there is no significant difference between the scores obtained in the pre- and post-cultural stage is refuted. ( $\mathrm{p}<0.05)$ As Table (11) illustrates, the mean of the students' scores has increased in the pre-cultural stage by 10.73 and in the post-cultural stage by 11.84 which establishes that there is a 1.11 or $\% 10$ raise in learning achievements of the students.

As the statistical results suggest, there has been a significant difference between the pre- and post-teaching stages in the experimental group. Teaching cultural theories of translation to students expands their views on translating process and what is required of a translator in a real translation context. This will directly affect their style of translating in a gradual process during the whole semester. A process which is not traced in the control groups which were run traditionally and without any direct or indirect teaching of the theories and were mainly practice-oriented.

\section{CONCLUSION}

Hopefully, the results of this study will shed more light on the positive effects of incorporating teaching cultural translation theories on translation quality of translator trainees in our universities. Moreover, due to lack of empirical studies in the literature, this study would hopefully contribute to the field in terms of the practicality and efficiency of teaching cultural translation theories in translation classes and improving the quality of students' translations. The findings can be applied to various translation courses in English literature, teaching, and translation majors at BA level. The findings can also be applied to other contexts in other countries in undergraduate university programs. Teaching cultural theories of translation to translation trainees and talking about different aspects of these theories in translation classes expand the trainees' views on translating process and would give them a bird-eye-view on the whole issue and consequently improve the quality of their translations.

\section{REFERENCES}

[1] Bassnett, S. (2002). Translation studies (Third ed.). London and New York: Routledge.

[2] Baker, M. (1997). The Routledge Encyclopedia of Translation Studies, London and New York: Routledge.

[3] Chesterman, A. \& Wagner, E. (2002). Can theory help translators? A dialogue between the ivory tower and the wordface. Manchester, UK \& Northampton, MA.

[4] Davies, M. G. (2004). Multiple voices in the translation classroom. Amsterdam/Philadelphia: John Benjamins Publishing Company.

[5] Duff, A. (1981). The Third Language; Recurrent Problems of Translation into English. Oxford: Pergamon.

[6] Farahzad, F. (1992). Testing achievement in translation classes. In C. Dollerup \& A. Loddegaard (Eds.), Teaching translation and interpreting: training, talent, and experience (pp. 271-278). Amsterdam/Philadelphia: John Benjamins Publishing Company.

[7] Federici,E. (2007). The translator's intertextual baggage. Forum for modern language studies, 43/2, 147-160.

[8] Gentile, A. (1991). The Application of theoretical constructs from a number of disciplines for the development of a methodology of teaching in Interpreting and translating. Meta, Vol. 36. No.2-3, 344-351. Retrieved October 18, 2008, from http://id.erudit.org/iderudit/002877ar

[9] Gile, D. (1991). Basic theoretical components in interpreter and translator training. In C. Dollerup \& A. Lindegaard (Eds.), Teaching Translation and Interpreting: Training, Talent, and Experience: Papers from the first language international 
conference (pp. 185-193). Elsindore, Denmark: John Benjamins publishing company.

[10] Munday, J. (2001). Introducing Translation Studies. Theories and Applications. London: Routledge.

[11] Newmark, P. (1988). A Textbook of Translation. New York: Prentice Hall.

[12] Venuti, L. (Ed.). (2000). The Translation Studies Reader. London and New York: Routledge.

Farzaneh Farahzad holds a Phd in TEFL from Allameh Tabatabai University, Tehran, Iran, where she has been teaching since 1980. She has been the editor-in-chief of the Iranian Journal of Translation Studies since 2000. As a professional translator/interpreter, Farahzad has been actively involved in writing on both theoretical and practical aspects of translation studies, her field of interest. Farahzad's papers have appeared in journals such as Perspectives, Translation, etc.

Parviz Azhideh is an Associate Professor in the English Department at Tabriz University, Iran. His research interests include reading, testing, ESP and translation. Ajideh's papers have appeared in journals such as The Reading Matrix, The Asian EFL Journal, Asian JDE, ELT (CCSE), etc.

Leila Razmjou is a PhD student in TEFL in Tabriz University, Iran. She holds an M.A. in TEFL from Shiraz University, Iran. She is working on her PhD thesis at the moment and teaching undergraduate courses in Tabriz University at the same time. Razmjou is particularly interested in Translation Pedagogy and has had a number of international conference papers and paper proceedings in this regard. 